\title{
Expression and Characterization of Recombinant Protein of J-SU pGEX either by Single or Double Cell Lysis
}

\author{
Ekspresi dan Karakterisasi Protein Rekombinan J-SU pGEX dengan Pemecahan Sel \\ Tunggal dan Ganda
}

\author{
Endang Tri Margawati* dan Muhamad Ridwan
}

Research Centre for Biotechnology, the Indonesian Institute of Sciences (LIPI)

Jl. Raya Bogor KM. 46. Cibinong 1691

E-mail: etmargawati@cbn.net.id*Penulis untuk korespondensi

\begin{abstract}
Abstrak
Penelitian ini dimaksudkan untuk optimasi produk protein rekombinan Superficial Unit dari virus Jembrana (JSU) yang dieksperikan melalui pemecahan sel secara tunggal dan ganda dengan sistem pGEX dalam skala flask $100 \mathrm{ml}$ media kultur. Dua metode pemecahan sel yang digunakan yaitu Freeze and Thaw (FT) sebagai pemecahan tunggal dan gabungan FT dan Sonikasi sebagai pemecahan ganda. Sel inang ( $E$. Coli pembawa konstruk JSU pGEX) ditumbuhkan dengan induksi IPTG pada $37^{\circ} \mathrm{C}$ dengan pengocok berkecepatan $200 \mathrm{rpm}$ sampai mencapai kepadatan sel 0,8 . Sel atau pelet dikoleksi dengan sentrifugasi, pelet dipecah dengan 2 perlakuan pemecahan sel tunggal dan ganda. Hasil pemecahan sel disentrifugasi untuk dikoleksi peletnya sebagai inclusion body. Solubilisasi dilakukan terhadap inclusion body dengan solubilisasi buffer dan diperoleh substrat protein JSU kemudian dimurnikan melalui Gluthation sepharose $4 \mathrm{~B}(500 \mu \mathrm{l}$ resin) dengan metode batch capture. Hasil karakterisasi dengan SDS PAGE dan Western Blotting menunjukkan ukuran protein JSU pGEX yang tepat yaitu 60kDa pada kedua sistem pemecahan sel. Namun demikian, pemecahan sel secara tunggal menghasilkan protein murni JSU pGEX lebih besar $(0.812 \mathrm{ng} / \mathrm{ul})$ dibanding pemecahan sel secara ganda $(0.486 \mathrm{ng} / \mathrm{ul})$. Dari penelitian ini dapat disimpulkan bahwa protein rekombinan JSU pGEX terekspresi lebih baik dengan metode pemecahan sel Freeze and Thaw.
\end{abstract}

Kata kunci: Protein rekombinan, JSU pGEX, ekspresi, pemecahan sel

Diterima: 26 Februari 2009, disetujui: 29 Juli 2009

\section{Introduction}

Jembrana disease is an acute and severe disease, endemic in Bali cattle (Bos javanicus). The disease caused a $20 \%$ case fatality rate after a short incubation period in Bali cattle (Moll, 1998). However, in the later publication the Jembrana Disease Virus (JDV) is also infecting to other cattle types and buffalo under experiment and they become infected under field condition (Soeharsono et al., 1995). Up to present, vaccination by using crude vaccine has been applied to prevent the Jembrana disease in Bali cattle (Hartaningsih and Wilcox, 1996;
Hartaningsih et al., 2001). The crude vaccine is provided from infected tissue of Bali cattle by Jembrana viruses. Availability of this crude vaccine is limited compared to recent population of Bali cattle in the field. Despite limited in production, the crude vaccine is also costly, less effective and demanding in vaccine maintenance.

Entering biotechnology era, it is possible to develop a conventional vaccine such as Jembrana vaccine by recombinant DNA technology to produce recombinant viral protein as Jembrana vaccine. Development of recombinant protein for potential vaccine was 
initiated by colleagues at Murdoch University for JDV. Initiation of producing a recombinant Jembrana vaccine is therefore expected to solve some of the problems associated with disadvantages of the current crude vaccine. This recombinant Jembrana vaccine is a safer, effective and lower production cost. JDV is identified as retrovirus disease belongs to lentivirus group of Retroviridae family (Chadwick et al., 1995; Wilcox et al., 1995). The genome of JDV is 7732bp in length (Chadwick et al., 1995). The JDV consists of at least three major genes (gag, pol and env) encoding proteins that needed for virus replications (Chadwick et al., 1995). The env gene encodes TM and SU proteins on the transmembrane and surface of the virus, respectively and most attempts to induce a protective immunity against lentivirus infection.

The Jembrana Superficial Unit (JSU) is one of potential candidate recombinant Jembrana vaccines that constructed in pGEX system. This JSU pGEX implemented GST tag as protein fusion. In its expression, the JSU therefore needs anti GST to recognize the JSU recombinant protein. This JSU was expressed through a host cell of Escherichia coli (E. coli) for producing recombinant protein.

A study on laboratory expression and purification of JSU pGEX performed a complicated procedure following the GST (glutathione-s-transferase) system (Amershampharmacia biotech, 1997). It is known that most of recombinant protein is always purified from $E$. coli after cloning of the gene into expression vectors (Studier and Moffatt, 1986; Studier et al., 1990). In prior to purification, there is a process of disrupting the cell membrane or termed as cell lysis by adding lysozyme to break the cell wall of E. coli. Cell lysis is the first step in cell fractionation and protein purification (Anonymous, 2008a). Many techniques are available for disruption of cells, including physical and detergent-based methods. The physical disruption of cells is such as Freeze and Thaw, and Sonication methods. The freeze and thaw methods involve exposure into liquid nitrogen and melt the protein substrate into warm water. Sonication lysis is breaking open cells using high frequency sound wave, it causes disruption of the bacterial cell wall (Anonymous, 2008b).

This present study was designed on implementation of two physical methods of cell lysis in the expression of JSU pGEX to optimize the protein yields. The effect of cell lysis methods was associated with the concentration of recombinant protein yields.

\section{Materials and Methods}

\section{Cell Growth and IPTG Induction}

Construct of J-SU pGEX in glycerol was taken out (10ul) and cultured into $5 \mathrm{ml}$ of Luria Broth (LB) medium (10.0 $\mathrm{g}^{-1}$ tryptone, 5 $\mathrm{g} \mathrm{l}^{-1} \mathrm{NaCl}, 5.0 \mathrm{~g} \mathrm{l}^{-1}$ yeast extract) containing $100 \mu \mathrm{g} / \mathrm{ml}$ amphicillin and incubated at $37^{\circ} \mathrm{C}$ by shaker at $200 \mathrm{rpm}$ overnight. The overnight culture was inoculated into $100 \mathrm{ml} \mathrm{LB}$ medium (in ratio of $1: 20$ ) and cultured at $37^{\circ} \mathrm{C}$ with shaker at 200rpm to achieve an optical density $\left(\mathrm{OD}_{600}\right)$ of 0.8 then induced with $0.1 \mathrm{mM}$ IPTG (Isopropyl-f1-D-thiogalactopyranoside) for another an hour. Induction of IPTG was aimed to stimulate the protein expression (Mills, 2001). The inoculated culture was centrifuged at $5000 \mathrm{rpm}$ at $4^{\circ} \mathrm{C}$ for 10 minutes to collect pellets and then kept at $-70^{\circ} \mathrm{C}$.

\section{Cell Lysis}

Two cell lyses performed in the treatments were:

\section{Freeze and Thaw (Single Lysis)}

The pellets taken out from a freezer ($70^{\circ} \mathrm{C}$ ) was exposure of liquid Nitrogen (liquid $\mathrm{N} 2$ ) for 30 seconds then thawed into a water batch at $42^{\circ} \mathrm{C}$ for 1 minute. This lysis of freeze and thaw (FT) was repeated for 5 times. Volume of $10 \mathrm{ml}$ lysis buffer $(100 \mathrm{mM}$ tris HCL $\mathrm{pH} 8 ; 5 \mathrm{mM}$ EDTA; $10 \%$ triton X 100) was added into the digested cells.

\section{Freeze-Thaw (FT) and Sonication (Double Lysis)}

This treatment was undertaken in combination of FT and Sonication treatments. The pellets was first digested by FT method as above (no 1) then followed by sonication for 3 
cycles ( 15 seconds digesting by ultra sonic with 1 minute interval). Sonication was conducted under condition of a lower temperature at $-4^{\circ} \mathrm{C}$ or sample was held on ice.

The collected substrate from both treatments (single and double lyses) was then centrifuged using $8000 \mathrm{rpm}$ at $4^{\circ} \mathrm{C}$ for 20 minutes to collect pellets. The pellets were inclusion body while the supernatant was termed as cell lysate (CL).

\section{Solubilization of Inclusion Body}

In prior to solubilization, the pellet (inclusion body) was washed with washing buffer $(50 \mathrm{mM}$ tris HCL pH 7.5; $50 \mathrm{mM} \mathrm{NaCl}$; $5 \%$ glycerol) three times, each washing was conducted by centrifugation of $8000 \mathrm{rpm}$ at $4^{\circ} \mathrm{C}$ for 15 minutes. After 3 times washing, the collected pellets (inclusion body) were solublelized with solubilization buffer (2M tris pH 12; 2M Urea; 20mM DTT; 1mM PMSF) on a rocker overnight to homogenize the substrate.

\section{Purification of Protein}

The collected substrate from sulubilization was then purified using Gluthation sepharose 4B (in $500 \mu \mathrm{l}$ resin) by a batch capture method on a rotator and then spun down to collect the substrate. First substrate collected from this purification was termed as inner volume (IV). The left resin was washed using washing buffer solution for twice and termed as Washing 1 and 2 (W1 and W2). The washed resin was eluted by elution buffer three times then termed as Elusion 1, 2 and 3 (E 1, E2 and E3). The collected elution was as final purified protein.

\section{Characterization of Protein}

The purified protein was identified on SDS PAGE (2 gels), one gel was for SDS protein identification and another gel was directly transferred on a Nitrocellulose membrane for Western Blot (WB) using primary goat antiGST antibody and secondary anti body of antigoat IgG (Rabbit) HRP conjugated (Amersham Biosciences). Characterization of purified protein was identified with a precision Plus Protein $^{\mathrm{TM}}$ dual color standards (BIORAD) to check the molecular weight of JSU pGEX.

\section{Quantification of Protein}

Purified protein was quantified by a GeneQuant machine at a wave length of $\lambda 280$ $\mathrm{nm}$ for protein concentration.

\section{Results and Discussion}

\section{Expression and Characterization of JSU}

In this study, expression of JSU pGEX was performed through Escherichia coli of BL21 strain. Characterization of JSU pGEX was conducted by using SDS-PAGE and WB on both cell lysis treatments where each lysis was repeated 3 times. The results showed that the size of JSU pGEX was performed at the right molecular weight $( \pm 60 \mathrm{kDa})$ at both treatments. Visualization of both SDS PAGE and WB derived from both cell lyses were presented (as a representative of 3 repetitions) on Figure 1 and Figure 2 of single and double treatments, respectively.

As showed on Figure 1 and 2, that JSU pGEX was well expressed through $E$. coli of BL21 strain at a right molecular weight of \pm 60 $\mathrm{kDa}$. As mentioned by Ramos et al., (2004) that BL21 strain of E. coli is suitable for expression of recombinant protein. In pGEX system, GST tag was used as protein fusion with molecular size of $26 \mathrm{kDa}$ (Amershampharmacia biotech, 1997) while the JSU protein has molecular weight of $\pm 34 \mathrm{kDa}$ (Chadwick et al., 1995). Therefore, the JSU pGEX has size of $\pm 60 \mathrm{kDa}$ as exactly the same size as found in this study.

It seems that cell digestion by FT method as a single treatment of cell lysis in this study was quite suitable for this JSU pGEX expression. This finding was proven by more thick and sharp bands on WB after SDS PAGE on Figure 1b (see at E1 and E2). Figure 1b, bands were showed thicker on CL and W1, 2 compared to that on all elution (E1, 2 and 3). It could be understood that at first expression was showed as the thickest band on CL since the protein was just expressed in supernatant as crude condition, and slightly degraded in thickness as at $\mathrm{W} 1$ and 2. The purified protein was the left protein bound on resin and after elution then the protein released as E1, 2 and 3 
and again the bands showed slowly degradation in band thickness.

From the expression of JSU pGEX by double cell lysis, it seems that the protein in WB was depleted (Figure 2a. and 2b.). The Physical digestion by double cell lysis illustrated that many proteins were lysed as shown on SDS PAGE (Figure 2a), even though there was a specific protein of JSU pGEX $( \pm 60 \mathrm{kDa})$ and exposed less thick (Figure $2 \mathrm{~b}$ ) compared to the single cell lysis (Figure 1b).

Specific expression of the size of JSU pGEX $( \pm 60 \mathrm{kDa})$ at WB was possibly due to the role of primary and secondary antibodies used in this study.



Figure 1. Characterization of JSU-pGEX derived from single cell lysis (Freeze-Thaw): a. SDS-PAGE; b. Western Blotting.

$(\mathrm{M}=$ Marker; $\mathrm{CL}=$ Cell lysate; IV= Inner volume; W1-W2=Washing1-2; E1-3= Elusion 1-3).

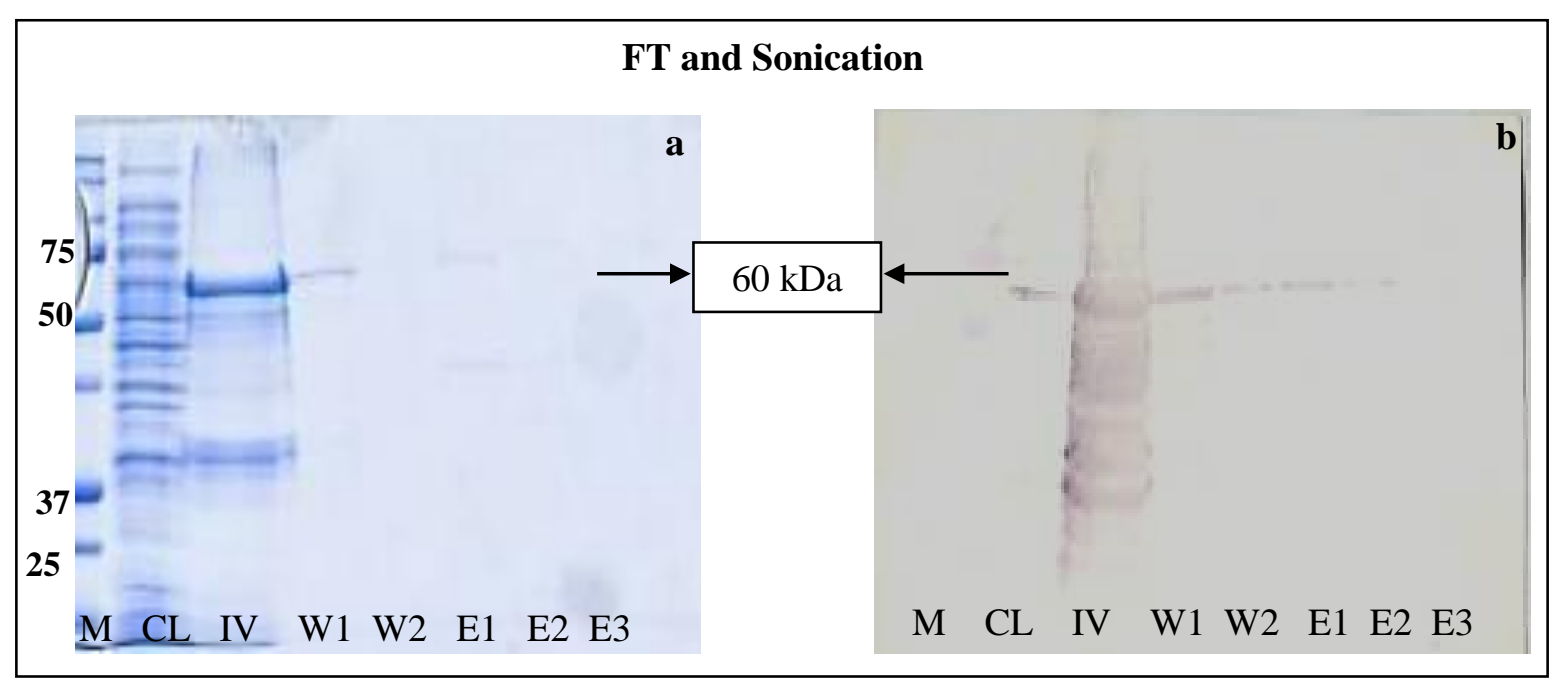

Figure 2. Characterization of JSU-pGEX derive from double cell lysis (Sonication and FT): a. SDS-PAGE; b. Western Blotting.

$(\mathrm{M}=$ Marker; $\mathrm{CL}=$ Cell lysate; IV= Inner volume; W1-W2=Washing1-2; E1-3= Elusion 1-3) 


\section{Quantification of JSU}

Expression of some recombinant viral proteins often produces in the form of inclusion body where it needs to be solublelized to get soluble protein or active protein. It is also occurring on JSU recombinant protein. As recommended by Singh and Panda (2005) that adding solubilization buffer into inclusion body is a method of protein solubilization to obtain soluble protein. This study was also using the solubilization buffer to solublelize the inclusion body of JSU pGEX recombinant protein.

In this study, the purified soluble protein of JSU pGEX resulting from protein purification was quantified by using a GeneQuant machine for protein calculation. Purified protein was obtained from three repetitions where each repetition was eluted three times, namely E1, E2 and E3. A total purified protein was averaged from those total three repetitions. Each elution (E) of those three repetitions from both derived cell lyses was presented on Table 1 .

Table 1 showed that averagely, purified recombinant protein JSU pGEX derived from single cell lysis resulted a higher concentration $(0.790 \mathrm{ng} / \mu \mathrm{l})$ compared to that double cell lysis $(0.447 \mathrm{ng} / \mu \mathrm{l})$. Double cell lysis was a combination of FT method and sonication (physical method). It seems that the effect of double cell lysis might heat and trigger to protein degradation, it is due to the effect of high temperature resulted from three cycles of sonication. Most of protein is composed by molecules that easily damage when it is not in the right physiology condition. Fractionation of cells is therefore should be performed at the lower temperature $\left(0-4^{\circ} \mathrm{C}\right.$ ) or on ice (Anonymous, 2008a) and at the certain condition of buffer and $\mathrm{pH}$ (Anonymous, 2009a). It seems that a higher physical cell lysis would more deplete the protein when it is not handled in the right way. As known, there are two types of protein degradation: by lysosomal and cytosolic, however the protein degradation is energy consuming process (Anonymous, 2009b). In this study, the effect of a physical cell lysis (sonication) might change the higher temperature into energy.

However based on the result of this study, it can be suggested that exposure of three cycles using ultra sound of sonication should be performed extra carefully and gently where protein should be managed on a lower temperature to avoid protein degradation. Overall, the protein was expressed in higher yield by a single cell lysis compared to that by double cell lysis.

Table 1. Concentration of JSU pGEX derived either by single or double cell lysis from 100ml culture.

\begin{tabular}{cccc}
\hline \hline \multirow{2}{*}{ Repetition } & Elusion $(\mathbf{E})$ & \multicolumn{2}{c}{ Concentration ng/ $\boldsymbol{\mu l}$} \\
& & Freeze \& Thaw (FT) & FT and Sonication \\
\hline \hline \multirow{2}{*}{1} & E1 & 0.952 & 0.330 \\
& E2 & 0.932 & 0.630 \\
& E3 & 0.752 & 0.303 \\
\cline { 2 - 4 } & Average & $\mathbf{0 . 8 7 9}$ & $\mathbf{0 . 4 2 1}$ \\
\hline \multirow{2}{*}{2} & E1 & 1.006 & 0.540 \\
& E2 & 0.429 & 0.410 \\
& E3 & 0.301 & 0.335 \\
\hline \multirow{2}{*}{3} & Average & $\mathbf{0 . 5 7 9}$ & $\mathbf{0 . 4 2 8}$ \\
& E1 & 1.158 & 0.268 \\
& E2 & 0.859 & 0.680 \\
& E3 & 0.716 & 0.532 \\
\hline \hline & Average & $\mathbf{0 . 9 1 1}$ & $\mathbf{0 . 4 9 3}$ \\
\cline { 2 - 4 } & Total average & $\mathbf{0 . 7 9 0}$ & $\mathbf{0 . 4 4 7}$ \\
\hline
\end{tabular}




\section{Conclusion}

This research concluded that both cell lysis systems (single and double) showed at the right size of $60 \mathrm{kDa}$ JSU pGEX on SDS PAGE and Western Blotting. However, a single cell lysis system yielded a higher pure recombinant protein of JSU pGEX $(0.812 \mathrm{ng} / \mathrm{ul})$ compared to that a double cell lysis system $(0.486 \mathrm{ng} / \mathrm{ul})$.

\section{Acknowledgment}

Authors thank to colleagues at the virology laboratory of the Murdoch University, Western Australia for providing JSU pGEX construct and extended appreciation to MS. Neneng Hasanah for her excellent assistance.

\section{References}

Amershampharmacia Biotech. 1997. GST Gene Fusion System. The $3^{\text {rd }}$ edition, revision 2. Amershampharmacia Biotech.

Anonymous. 2008a. Cell Lysis. http://www.piercenet.com/ Proteomics/browse.cfm?fldID $=72$ F377CD2581-438C-9B27-5360226EA128.12/19/2008.

Anonymous. 2008b. Sonication. Electronic Paper. http://matcmadison.edu/biotech/resources/prot eins/purification/sonicGuide.htm. 12/19/2008.

Anonymous. 2009a. Lecture 13-Dasar-dasar Isolasi Protein. http://inherent.brawijaya.ac.id/biomol/ materi/lecture13.pdf. 01/26/2009.

Anonymous. 2009b. Protein Degradation. http://www.uta. edu/biology/wilk/calsnotes/cellphys/protein\% 20defradation.pdf. 02/25/2009.

Chadwick, B.J., Coelen, R.J., Sammels, L.M., Kertayadnya, G. and Wilcox, G.E. 1995. Nucleotide Sequence Analysis of Jembrana Disease Virus: A New bovine Lentivirus Associated with an Acute Disease Syndrome. J. Gen. Virol.76: 1637-1650.

Hartaningsih, N., Dharma, D.M.N., Soeharsono, S. and Wilcox, G.E. 2001. The Induction of a Protective Immunity Against Jembrana Disease in Cattle by Vaccination with Inactivated Tissue-Derived Virus Antigens. Vet. Immunol. and Immunopathol. 78: 163176.
Hartaningsih, N. and Wilcox, G.E. 1996. Jembrana Disease Caused by a Pathogenic Bovine Lentivirus - Induction of Protective Immunity in Cattle by Vaccination. Abstract. The $\mathrm{X}^{\mathrm{th}}$ Int. Congress of Virology, Jerusalem, Israel, August 1996. p. 258.

Mills, A.A. 2001. Changing Colors in Mice: an Inducible System that Delivers. Genes and Development 15: 1461-1467.

Moll, H. 1998. Report of the UNOPS Marketing and Rural Finance Expert. In, Supervision Report, Eastern Islands Smallholder Farming Systems and Livestock Development Project. United Nations Office for Project Services (UNOPS), 18 September 1998. p. 65-69.

Ramos, C.R.R., Abreau, P.A.E., Nascimento, A.L.T.O. and Ho, P.L. 2004. A High-Copy T7 Escherichia coli Expression Vector for the Production of Recombinant Proteins with a Minimal N-Terminal His-Tagged Fusion Peptide. Brazilian J. of Medi. and Biol. Research 37 (8): 1103-1109.

Singh, S.M. and Panda, A.K. 2005. Solubilization and Refolding of Bacterial Inclusion Body Proteins. J. of Bioscience and Bioengineering 99 (4): 303-310.

Soeharsono, S., Wilcox, G.E., Dharma, D.M.N., Hartaningsih, N., Kertayadnya, G. and Budiantono, A. 1995. Species Differences in the Reaction of Cattle to Jembrana Disease Virus Infection. J. of Comp. Pathol. 112: 391402.

Studier, F.W. and Moffatt, B.A. 1986. Use of Bacteriophage T7 RNA Polymerase to Direct Selective High-Level Expression of Cloned Genes. J. of Mol. Biol. 189: 113-130.

Studier, F.W., Rosenberg, A.H., Dunn, J.J. and Dubendorff, J.W. 1990. Use of T7 RNA Polymerase to Direct of Clone Genes. Methods in Enzymology 185: 60-89.

Wilcox, G.E., Chadwick, B.J. and Krtayadnya, G. 1995. Jembrana Disease Virus: A New Bovine Lentivirus Producing an Acute Severe Clinical Disease in Bos Javanicus Cattle. Abstract. The $3^{\text {rd }}$ International Congress on Veterinary Virology, Interleken, Switzerland 4-7 September 1994. 